\title{
Drosophila C/EBP: a tissue-specific DNA-binding protein required for embryonic development
}

\author{
Pernille Rørth ${ }^{1}$ and Denise J. Montell ${ }^{2}$ \\ Howard Hughes Research Laboratory, Department of Embryology, Carnegie Institution of Washington, Baltimore, Maryland \\ 21210 USA
}

\begin{abstract}
Recently, we reported the cloning of the Drosophila melanogaster homolog of the vertebrate CCAAT/enhancer-binding protein (C/EBP). Here, we describe studies of the DNA-binding and dimerization properties of Drosophila C/EBP (DmC/EBP), as well as its tissue distribution, developmental regulation, and essential role in embryonic development and conclude that it bears functional as well as structural similarity to mammalian C/EBP. DmC/EBP contains a basic region/leucine zipper (bZIP) DNA-binding domain very similar to that of mammalian C/EBP and the purified C/EBPs bound to DNA with the same sequence specificity. Among the DNA sequences that DmC/EBP bound with high affinity was a conserved site within the promoter of the DmC/EBP gene itself. In vitro, DmC/EBP and mammalian C/EBP specifically formed functional heterodimers; however, as we found no evidence for a family of DmC/EBPs, DmC/EBP may function as a homodimer in vivo. The DmC/EBP protein was expressed predominantly during late embryogenesis in the nuclei of a restricted set of differentiating cell types, such as the lining of the gut and epidermis, similar to the mammalian tissues that express C/EBP. We have characterized mutations in the DmC/EBP gene and found that deleting the gene caused late embryonic lethality. Embryos that lack C/EBP die just before or just upon hatching. The lethal phenotype of C/EBP mutants can be rescued with the cloned $\mathrm{C} / \mathrm{EBP}$ gene introduced by $\mathrm{P}$-element-mediated germ-line transformation. The strict requirement for $\mathrm{C} / \mathrm{EBP}$ during Drosophila embryogenesis, coupled with its structural and functional similarities to mammalian $\mathrm{C} / \mathrm{EBP}$, provides a useful genetic system in which to study the role of C/EBP in development.
\end{abstract}

[Key Words: Drosophila; C/EBP; DNA-binding protein; transcription; cell differentiation]

Received August 26, 1992; revised version accepted October 14, 1992.

Complex multicellular organisms contain a large number of different sequence-specific DNA-binding proteins that serve to regulate transcription [for reviews, see Trends Biochem. Sci. 16 (11), 1991]. Transcription factors play a central role in the control of cell growth and differentiation by ensuring appropriate tissue-specific gene expression and are therefore intensely studied with respect to both molecular structure and biological function. Analysis of transcription factors at the molecular level has revealed that they are composed of distinct functional domains, which can often be recognized from the primary amino acid sequence as conserved structural motifs. DNA-binding domains have been characterized most extensively and can serve to order transcription factors into families of zinc finger, helix-turn-helix, helix-loop-helix, and basic region/leucine zipper (bZIP) DNA-binding proteins (for review, see Harrison 1991). To elucidate the in vivo functions of transcription fac-

\footnotetext{
${ }^{1}$ Corresponding author.

2Present address: Department of Biological Chemistry, The Johns Hopkins University School of Medicine, Baltimore, Maryland 21205 USA.
}

tors, both genetic and reverse-genetic approaches have been employed successfully. Furthermore, information gained about a transcription factor in one organism has been useful in predicting the roles of homologous factors in other organisms, for example, the involvement of homeo domain proteins in body axis patterning in both Drosophila and mammals (for review, see McGinnis and Krumlauf 1992).

The mammalian transcription factor C/EBP [CCAAT/ enhancer-binding protein) is the archetypical member of a subfamily of bZIP proteins. C/EBP /also termed C/EBP$\alpha)$ was originally isolated from rat liver nuclei (Graves et al. 1986; Johnson et al. 1987; Landschulz et al. 1988) and has since been found in several other tissues, including fat, lung, intestine, and skin (Birkenmeier et al. 1989). $\mathrm{C} / \mathrm{EBP}$ is found in the terminally differentiated cells of these tissues and has, in several cases, been shown to regulate genes that are required for the differentiated phenotype (Christy et al. 1989; Friedman et al. 1989). A central role for C/EBP has been established in adipose differentiation of cultured 3T3-L1 cells, in which cessation of mitotic growth normally precedes, and is a pre- 
requisite for, differentiation into fat cells. Umek and colleagues showed that ectopic expression of C/EBP early in the differentiation program resulted in abrupt and premature growth arrest (Umek et al. 1991). More recent studies of the 3T3-Ll cell system have confirmed that C/EBP expression is necessary for adipocyte conversion (Samuelsson et al. 1991; Lin and Lane 1992) and is sufficient to activate the differentiation switch (Freytag et al. 1992). Similarly, the C/EBP protein is found in differentiating, postmitotic hepatocytes, enterocytes, and keratinocytes (Birkenmeier et al. 1989; Z. Cao, P. Rørth, and S. McKnight, unpubl.). Such observations raise the possibility that $\mathrm{C} / \mathrm{EBP}$ is required in vivo to induce the terminal differentiation program in different cell types.

Recent studies have identified a group of proteins that share extensive amino acid sequence similarity with the DNA-binding domain of C/EBP. The first of these to be described was NF-IL6 (Akira et al. 1990), which has also been termed liver activator protein (LAP; Descombes et al. 1990), IL-6 D-element-binding protein (IL-6DBP; Poli et al.1990), C/EBP-related protein (CRP-2) (Williams et al. 1991), and C/EBP- $\beta$ (Cao et al. 1991). Three additional proteins showing this sequence similarity to C/EBP have subsequently been characterized: immunoglobulin enhancer-binding protein 1 (Ig/EBP-1) (Roman et al. 1990), CRP-1 (Williams et al. 1991), and C/EBP- $\delta$ (Cao et al. 1991). These transcription factors, and C/EBP itself, bind to the same DNA sequences and can form functional heterodimers with one another both in vitro and in vivo (C/EBP and CRP-2; Williams et al. 1991). Based on their ability to heterodimerize, their ability to recognize the same DNA sequences, and the similarity of their bZIP domains at the amino acid sequence level, these proteins are collectively called C/EBP family members, or C/EBP isoforms.

Studies of their expression patterns reveal that several mammalian C/EBP isoforms may coexist in one cell, allowing formation of distinct heterodimeric C/EBP molecules and complicating the determination of which $\mathrm{C} / \mathrm{EBP}$ isoforms regulate potential target genes containing C/EBP-binding sites. The C/EBP isoforms may also overlap in function, leading to some redundancy. Whereas continued work on each of the mammalian C/EBP isoforms will help to clarify their respective functions, our approach to understanding the functions of $\mathrm{C} / \mathrm{EBP}$ in vivo has been to study it in a simpler, genetically accessible organism Drosophila melanogaster.

The Drosophila gene encoding C/EBP was cloned by virtue of P-element insertions at the slow border cell (slbo) locus that disrupt a specific cell migration process during oogenesis (Montell et al. 1992). The predicted protein product of the Drosophila C/EBP (DmC/EBP) gene shows striking sequence similarity to its mammalian counterparts in the bZIP region. To determine whether DmC/EBP is a functional as well as structural homolog of mammalian C/EBP, we have characterized its DNA binding and dimerization properties and its role during embryonic development. DmC/EBP is expressed late in embryogenesis; and consistent with this, null mutations in the C/EBP gene cause late embryonic lethality. DmC/
EBP is expressed in a tissue-specific pattern similar to the expression pattern of C/EBP in mammals, suggesting that the protein may play similar roles in different organisms. Identification of a functional C/EBP homolog in Drosophila, coupled with the finding that this single C/EBP gene is essential for Drosophila development, opens the possibility of a genetic approach to analyzing the biological function of this transcription factor.

\section{Results}

\section{In vitro characterization of the $D m C / E B P$ protein}

Vertebrate C/EBP contacts its specific DNA substrate by an $\sim 20$ amino-acid-long basic region (Landschulz et al. 1989; Agre et al. 1989; Shuman et al. 1990). Conceptual translation of the Drosophila slbo gene (Montell et al. 1992) resulted in a protein with $19 / 21$ amino acid identities to the vertebrate C/EBP in the basic region (Fig. 1A). This striking sequence similarity indicated to us that the slbo gene encoded a DNA-binding DmC/EBP protein and, furthermore that DmC/EBP would bind DNA with a specificity similar to the mammalian C/EBPs. To test these predictions, two recombinant derivatives of the $\mathrm{DmC} / \mathrm{EBP}$ protein were expressed in bacteria and purified to homogeneity (see Materials and methods). The 07 protein was full length, except for the elimination of 22 glutamine residues located close to the amino terminus (Fig. 1B). The BRLZ protein was much shorter and contained only the 90-amino-acid bZIP domain. Quantitative electrophoretic gel mobility shift assays (EMSAs) were employed to compare the DNA-binding properties of the recombinant DmC/EBP proteins with corresponding derivatives of the mammalian C/EBP- $\alpha$ protein. In the example shown in Figure 2, fulllength mammalian C/EBP and DmC/EBP proteins were allowed to bind to a labeled oligonucleotide containing a high-affinity C/EBP-binding site (Shuman et al. 1990). To test the sequence specificity of binding, the same unlabeled oligonucleotide and two oligonucleotides with 4-nucleotide changes were titrated as competitors for binding. In this as well as in other competition experiments, DmC/EBP and mammalian C/EBP- $\alpha$ bound DNA similarly, as did endogenous DmC/EBP from embryo nuclear extracts (data not shown).

Immediately adjacent to the basic region within the bZIP domain is the leucine zipper, the region of the protein responsible for dimerization. The leucine zipper domains of the mammalian C/EBPs are not as similar in primary amino acid sequence as the basic regions are (Fig. 1A). Compared with C/EBP- $\alpha$, the two most related proteins are C/EBP- $\beta$ and C/EBP- $\delta$, which show $73 \%$ amino acid identity within the leucine zipper, whereas Ig/EBP-1 shows only $32 \%$ identity; yet all of these proteins specifically heterodimerize. Another bZIP protein such as c-Jun, which does not heterodimerize with the C/EBPs, shows $24 \%$ amino acid identity with C/EBP- $\alpha$ in this region. The leucine zipper of $\mathrm{DmC} / \mathrm{EBP}$ bears only 8 of 37 amino acid identities $(22 \%)$ to C/EBP- $\alpha$ and, 


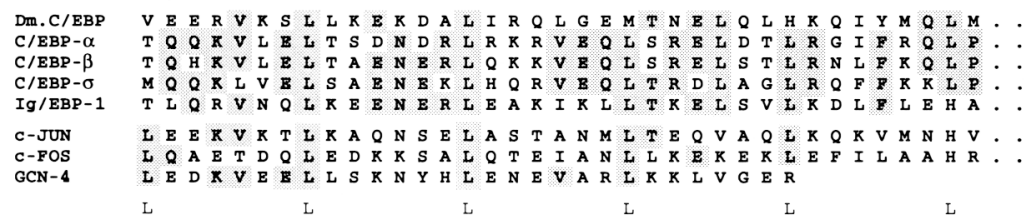

B

$\mathrm{Dm}$ C/EBP

C/EBP o7

C/EBP BRLZ

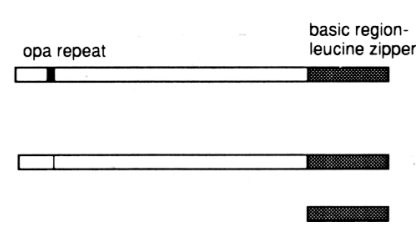

Figure 1. DmC/EBP protein structure. $(A)$ Alignment of the basic region and the leucine zipper of DmC/EBP with the identified mammalian C/EBPs. Three other bZIP transcription factors are aligned underneath. Amino acid identities, when found in at least three of the C/EBPs, are highlighted. The amino acid sequences shown are C/EBP- $\alpha, 278-346$ (Landschulz et al. 1988); C/EBP- $\beta$, 218-286 and C/EBP-8, 187-255 (Cao et al. 1991); Ig/EBP-1, 126-194 (Roman et al. 1990); c-Jun, 251-319 (Bohmann et al. 1987); c-Fos, 133-201 (van Straaten et al. 1983); and GCN4, 221-281 (Hinnebusch 1984). (B) Schematic representation of the 444-amino-acid $\mathrm{DmC/EBP}$ protein and the variants expressed in E. coli and used in this study. C/EBP o7 is full length, with a deletion of amino acids 45-68. C/EBP BRLZ contains amino acids 354-444.

for example, 9 of 37 identities to c-Jun, making it difficult to predict whether the DmC/EBP zipper is functionally related to the other C/EBP zippers. To analyze the function and specificity of the DmC/EBP zipper, we tested the dimerization properties of DmC/EBP according to the method of Hope and Struhl (1987). Proteins of distinct molecular mass were mixed as specified in Figure $3 \mathrm{~A}$, a radiolabeled probe was added, and the complexes were analyzed by EMSA. Appearance of a proteinDNA complex with intermediate mobility indicated heterodimerization. DmC/EBP bound DNA as a dimer and could form a DNA-binding heterodimer with C/EBP- $\alpha$

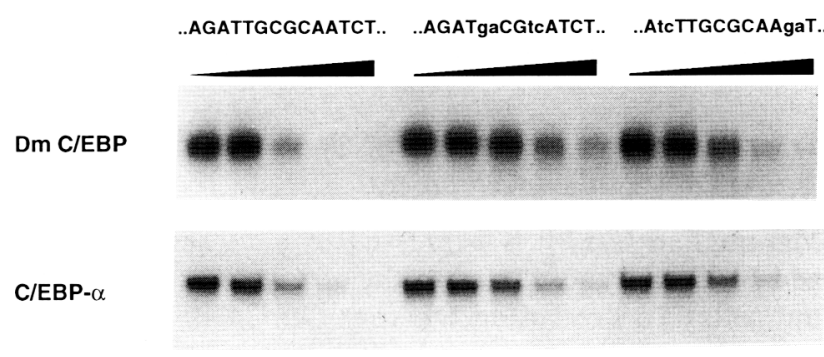

Figure 2. EMSA comparing the DNA-binding specificity of the $\mathrm{DmC} / \mathrm{EBP}$ and the mammalian C/EBP protein. Approximately $20 \mathrm{ng}$ of the DmC/EBP protein (o7) (top) or the C/EBP- $\alpha$ protein $(\Delta 1-2)$ (bottom), was incubated with a mixture of labeled oligonucleotide containing a high affinity C/EBP-binding site (5'TGCAGATTGCGCAATCTGCA-3') and increasing amount of the unlabeled competitor indicated above the lanes. From left to right, 0, 2, 10, 50, and 250 times molar excess of the competitor was used. All competitors were dyad symmetrical 20 -mers identical to the labeled oligonucleotide except for the changes indicated in lowercase letters. Shown is the band representing protein complexed to labeled DNA. but not with GCN4, another bZIP protein outside of the C/EBP family. In additional experiments we observed the theoretically expected $1: 2: 1$ ratio between homodimers and heterodimers of full-length and truncated DmC/EBP, whereas heterodimers were under-represented when mixing DmC/EBP and C/EBP- $\alpha$, indicating a slight difference in the dimerization properties of DmC/EBP and mammalian C/EBP.

To determine which part of the C/EBP- $\alpha$ protein was responsible for its selectivity in heterodimerization, we expressed and purified a GCN4/C/EBP- $\alpha$ fusion protein called $\mathrm{G}_{1} \mathrm{C}_{1}$, which contained the zipper region from $\mathrm{C} / \mathrm{EBP}-\alpha$, but was otherwise entirely GCN4 (Agre et al. 1989). The $G_{1} C_{1}$ protein was capable of dimerizing with both C/EBP- $\alpha$ and DmC/EBP but not with GCN4 (Fig. $3 \mathrm{~B})$. This confirmed that the specificity of dimerization was dictated entirely by the identity of the leucine zipper, as has been shown for other bZIP proteins (Kouzarides and Ziff 1988), and that, based on zipper interaction specificity, DmC/EBP qualified as a C/EBP family member.

\section{D. melanogaster may encode only a single $C / E B P$}

Because there is a family of C/EBP proteins in vertebrates and because the ability to specifically heterodimerize with other C/EBP proteins is conserved in $\mathrm{DmC} / \mathrm{EBP}$, we considered that there could be other C/EBP isoforms in Drosophila. We searched for additional C/EBP isoforms by screening a genomic library with a $C / E B P$ basic region probe under conditions identical to those used to isolate C/EBP- $\beta$ and C/EBP- $\delta$ with a C/EBP- $\alpha$ probe (Cao et al. 1991). The probe corresponded to the DmC/EBP basic region (amino acids 354380). This region is very well conserved between all 
A

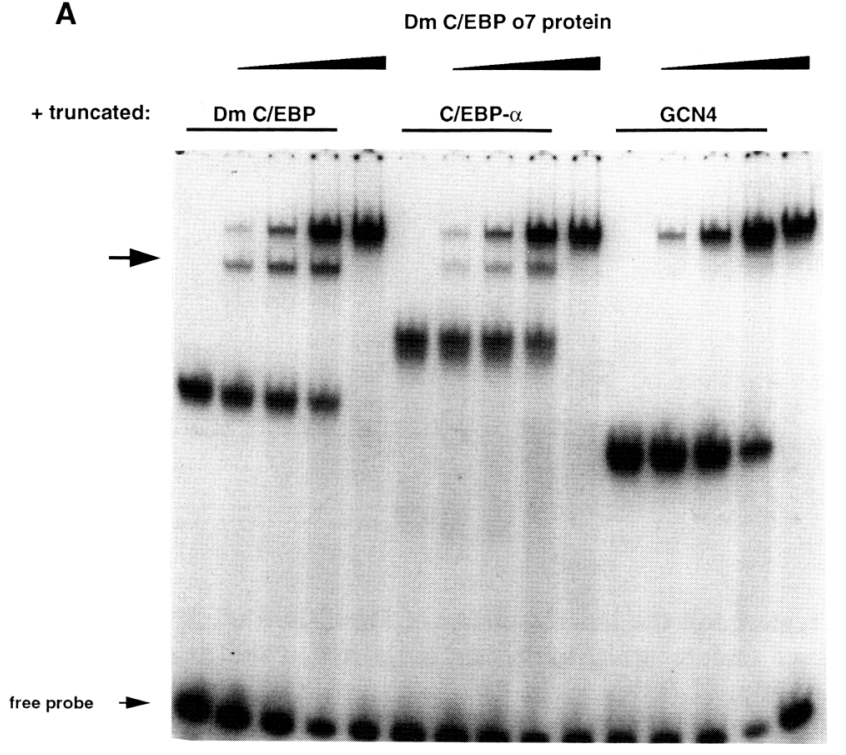

B

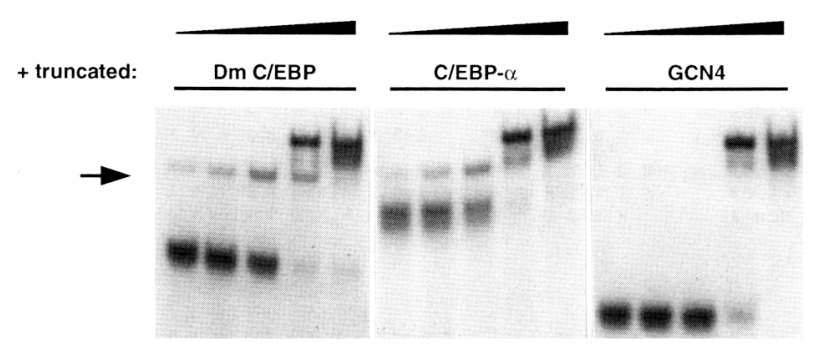

Figure 3. EMSA showing dimerization properties of DmC/EBP protein. The indicated purified polypeptides were premixed to allow subunit exchange before the addition of labeled oligonucleotide and the separation of the resulting complexes on nondenaturing polyacrylamide gels. The truncated forms of the proteins contain the complete DNA-binding bZIP domains: for DmC/EBP, amino acids $354-444$; for C/EBP- $\alpha, 272-346$; for GCN4, 228-281. The arrow indicates the position of heterodimers. $(A)$ Constant amount of the indicated truncated protein assayed alone (lanes $1,6,11)$ or mixed with an increasing amount of the full-length DmC/EBP protein (07). Lanes 5, 10, and 15 show o7 protein alone. (B) Constant amount of the indicated truncated protein mixed with an increasing amount of the GlCl recombinant fusion protein [GCN4 with the zipper of C/EBP- $\alpha$ (Agre et al. 1989)]. The slight smear seen below the GlCl homodimer band was also observed with this protein alone.

$\mathrm{C} / \mathrm{EBP}$ isoforms and shows $63 / 81$ nucleotide identities between C/EBP- $\alpha$ and DmC/EBP. Twenty genome equivalents of the Maniatis Drosophila genomic $\lambda$ phage library were screened under low stringency conditions. Of 8 strongly hybridizing clones, all 8 contained the identified DmC/EBP itself. Of 20 more weakly hybridizing clones, 20 were all unrelated to one another; and when sequenced, the hybridizing region had 30-35 nucleotide identities to the probe and no potential for encoding a C/EBP homolog.

\section{$D m C / E B P$ binds to a conserved site in the promoter of its own gene}

Having determined that DmC/EBP was a sequence-specific DNA-binding protein, we searched for a genomic C/EBP-binding site that might be an in vivo target for the protein. The observation that many transcription factors autoregulate in vivo prompted us to focus this analysis on the promoter of the DmC/EBP gene itself. As a first step, the transcription start sites for the DmC/EBP mRNA were identified. Two major transcription start sites of C/EBP mRNA, P1 (distal) and P2 (proximal), were found by primer extension analysis (Fig. 4A,D). The start sites were confirmed by repeating the primer extensions with primers that hybridized to alternate positions and by $\mathrm{S} 1$ nuclease mapping (data not shown). A canonical TATA box was found 20-25 bp upstream of the P2 transcription start site. No obvious TATA box was found near the P1 start site. $5^{\prime}$-End-labeled DNA fragments corresponding to the promoter region were incubated with the DmC/EBP protein and subjected to DNase I digestion to reveal protein-binding sites. This footprinting analysis identified a C/EBP-binding site between the P2 TATA box and the P2 transcription start site (Fig. 4B,C).
The $\sim 15$ bp binding site was completely protected by 5 ng of the C/EBP BRLZ protein, showing that it was recognized with high affinity by the DmC/EBP protein.

We found that the C/EBP-binding site at P2 was conserved in the Drosophila virilis gene encoding C/EBP, suggesting that the C/EBP-binding site in the C/EBP promoter is functionally significant. Comparison of the C/EBP structural gene and part of the upstream region from $D$. melanogaster with that of the distantly related $D$. virilis revealed that outside of the coding region, the most conserved sequence between these species was the complex of the P2 TATA box, the C/EBP-binding site, and the P2 transcription initiation site (Fig. 4D). The complex shows $33 / 39$, or $85 \%$, nucleotide identity between the two species, whereas the surrounding $200 \mathrm{bp}$ of nontranslated sequence are $33 \%$ identical.

\section{Temporal and spatial pattern of C/EBP expression during Drosophila development}

Mammalian C/EBP is expressed in a subset of tissues and is generally restricted to the terminally differentiating cells. To determine whether DmC/EBP had these same characteristics, we examined its temporal and spatial expression during development. Northern blot analysis of RNA prepared from various stages of Drosophila development revealed the highest level of C/EBP mRNA during embryogenesis (Fig. 5). Longer exposures of Northern blots revealed C/EBP mRNA in the adult ovary, consistent with the observation that C/EBP is required during oogenesis (Montell et al. 1992) and in second-instar larvae. Having detected a significant amount of C/EBP mRNA in unstaged embryos, we investigated the temporal pattern of expression in more detail using staged embryos. Primer extension analysis (Fig. 6A), as 
A

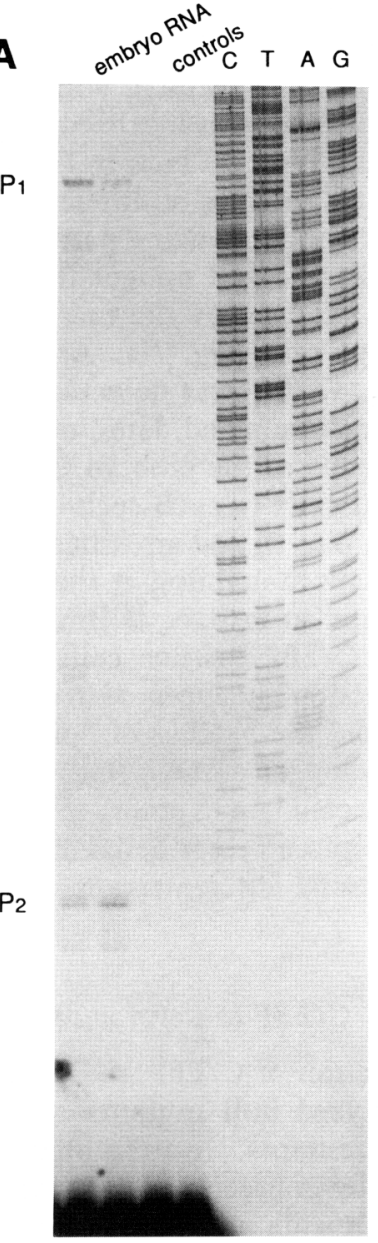

B

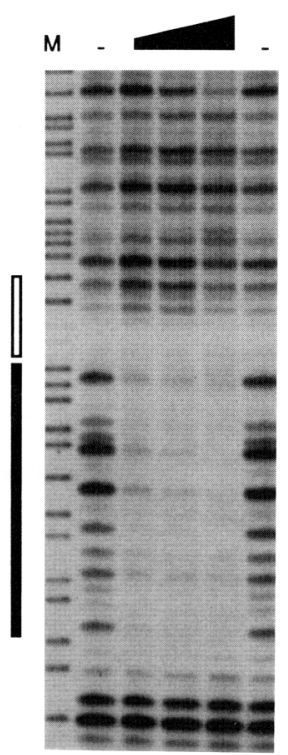

C

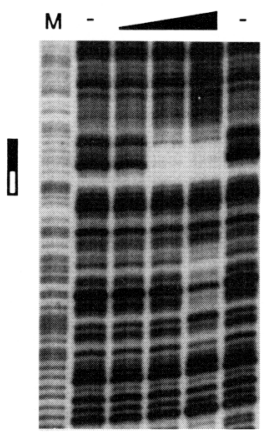

D

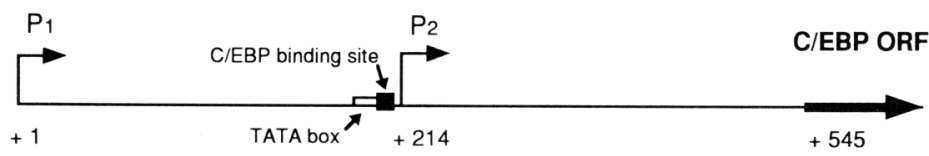

D.melanogaster

D.virilis

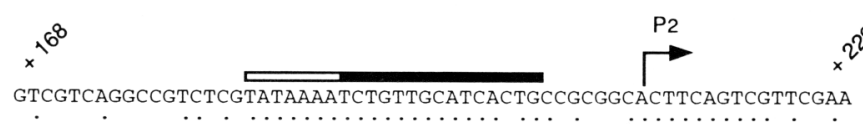

ATAAAGAAATACTCGCATATAAAATCTGTTGCATCATTGCTGAAACACTTCAGTCGCTGAAT
Figure 4. DmC/EBP bound to its own promoter. $(A)$ Primer extension analysis showing the two major transcription start sites for C/EBP mRNA, Pl (designated position +1 ) and $\mathrm{P} 2$ (position +214 ). The primer was complimentary to positions +278 to +247 . Embryo RNA (lanes 1,2) was from two different batches of wild-type embryos. Negative controls were mammalian ES cell RNA (lane 3), and yeast tRNA (lane 4). The sequencing ladder was generated with the same primer and cloned genomic DNA as template. $(B, C)$ Footprint analysis of the P2 promoter region. Lanes $M$ are Maxam-Gilbert $G+A$ marker lanes. The minus sign $(-)$ indicates DNase I digestion in the absence of protein. The site protected from digestion by DmC/EBP protein is marked by a box, the TATA box is marked by a box. $(B)$ Lower strand. The fragment was labeled at position +233 and extends to position +55 . Amounts of 5,50, and $500 \mathrm{ng}$ of the DmC/EBP BRLZ protein were added in lanes 3,4 and 5, respectively. $(C)$ Upper strand. The fragment was labelled in vector sequence adjacent to position +55 and extends past the P2 transcription start site; 25 fmoles of DNA was used per lane. Amounts of $0.5,5$, and $50 \mathrm{ng}$ of C/EBP BRLZ protein were added to lanes 3,4 , and 5, respectively. (D) Schematic representation of the C/EBP promoter region and a sequence comparison between the $\mathrm{P} 2$ region of $D$. melanogaster $\mathrm{C} / \mathrm{EBP}$ and the corresponding putative promoter region in $D$. virilis /cloning of both genes is reported in Montell et al. 1992). well as Northern blot analysis (data not shown), of RNA prepared from staged embryos showed that C/EBP mRNA first appeared $8 \mathrm{hr}$ postfertilization and peaked at 12-16 hr of development.

Experiments addressing the temporal expression pattern of the C/EBP protein were carried out by Western blot analysis using total protein extracts from staged embryos and probing with antisera specific to DmC/EBP (see Materials and methods). The antisera recognized a protein of $55 \mathrm{kD}$ apparent molecular mass, which was present late in embryogenesis (Fig. 6B). We concluded that this was C/EBP on the basis of its recognition by all three antisera, its apparent molecular weight, which was similar to the molecular weight predicted from the de- duced amino acid sequence $(51 \mathrm{kD})$, and a developmental expression pattern that closely correlated with that of C/EBP mRNA. There was no detectable maternal contribution of the C/EBP protein or expression in the early embryo. The C/EBP protein was clearly detectable at 12-18 hr of development but declined to undetectable levels by the end of embryogenesis. In parallel Western blot experiments, as well as in immunostaining, no C/EBP protein was detected in larval tissues (fat body, malpighian tubules, gut, salivary gland, imaginal disks, and brain from third-instar larvae; data not shown).

Whole-mount immunostaining was performed to determine the spatial pattern of C/EBP expression in the developing embryo. To avoid background staining prob- 


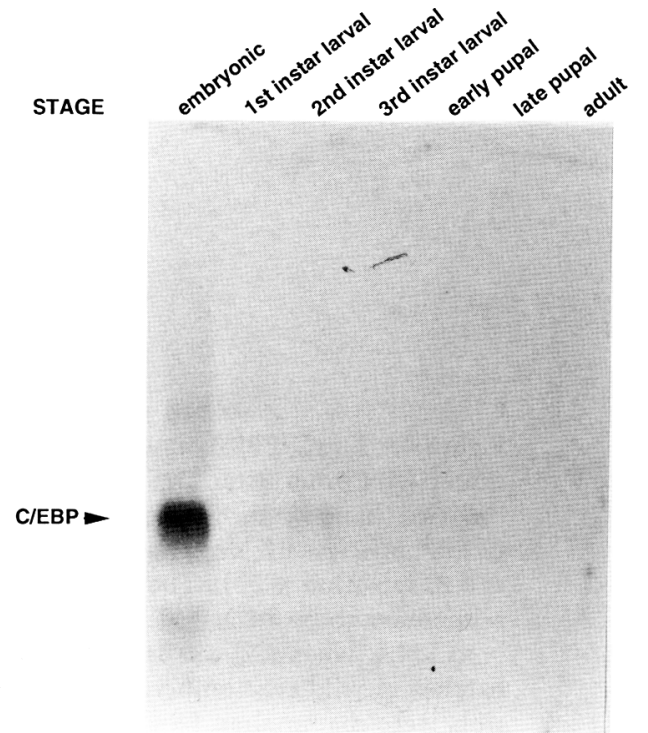

Figure 5. Expression of C/EBP mRNA during Drosophila development, as detected by Northern blot analysis. Poly $|\mathrm{A}|^{+}$ RNA from the indicated stages was separated on a denaturing gel, transferred to membrane, and probed with the DmC/EBP coding region (with the $\mathrm{CA}^{\mathrm{A}} / \mathrm{G}$ repeat corresponding to amino acids $45-68$ deleted).

lems, the C/EBP antibodies were affinity purified for this analysis (see Materials and methods). Several representative embryos stained with C/EBP antibodies are shown in Figure 7. The earliest detectable C/EBP expression was at 9-10 hr postfertilization in cells associated with the posterior spiracles (Fig. 7A,B), but the highest overall levels of C/EBP protein were detected at $12-18 \mathrm{hr}$ of development (Fig. 7C-J), in agreement with the Western blot analysis. C/EBP was nuclear localized, as seen most clearly in the high magnification view in Figure 7J. After $12 \mathrm{hr}$ of development a number of different tissues expressed C/EBP in a rapidly changing pattern. The salivary gland, proventriculus, and midgut (Fig. 7C-F) expressed C/EBP first, followed by the fore- and hindgut (Fig. 7G) and the epidermis (Fig. 7H). At the onset of epidermal expression, C/EBP was detected in most nuclei thoughout the epidermis and, later, only at the anterior and posterior ends of the embryo (Fig. 7I). However, a few epidermal cells in each segment retained a high level of staining (Fig. 7J and arrowheads in Fig. 7I), showing that the localized staining at the anterior and posterior ends was not an artifact of limited antibody access. These latter C/EBP-positive cells were of unknown origin and function but appeared in a segmentally repeated pattern, as did the patches of nonstaining epidermal cells in the younger embryo (Fig. $7 \mathrm{H}$ ). In summary, C/EBP was detected late in embryogenesis, in several morphologically distinct epithelial tissues during the time of their terminal differentiation.

\section{Functional studies of C/EBP in developing embryos}

To establish the function of C/EBP in Drosophila embryogenesis, we analyzed null mutants of the C/EBP gene. To obtain such mutants, we attempted to generate deletions in the gene by imprecise excision of P-element insertions located immediately $5^{\prime}$ of the C/EBP tran-

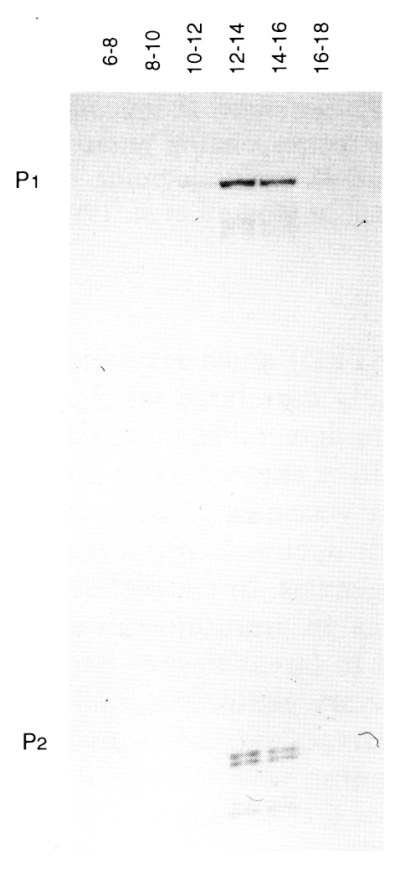

B
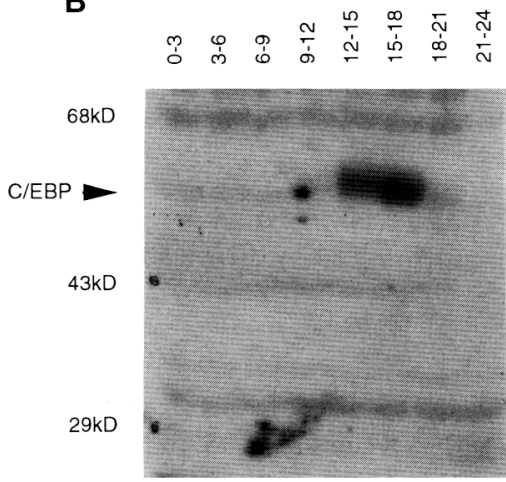

Figure 6. Expression of C/EBP $m R N A$ and protein during Drosophila embryogenesis. $|A|$ Detection of C/EBP mRNA by primer extension. Total RNA was prepared from wild-type embryos at different stages of embryogenesis (hours at $25^{\circ} \mathrm{C}$ are indicated). Total RNA (50 $\mu \mathrm{g}$ ) was used for quantitative primer extension analysis using the same C/EBP-specific oligonucleotide as in Fig. 4A. (B) Detection of C/EBP protein by Western blot analysis. Total protein extracts from staged (hours at $25^{\circ} \mathrm{C}$ ) wild-type embryos were separated on $10 \%$ SDS-polyacrylamide gels and blotted onto a nitrocellulose filter. The filter was stained for protein to ensure equal loading and transfer, probed with anti-DmC/EBP C135 antibody /see Materials and methods), and visualized with ${ }^{125}$ I-labeled protein A. Band C/EBP (arrowhead) was not detected by preimmune sera, whereas background bands seen in all lanes were detected by preimmune serum from the same animal but not when using serum from another animal. 


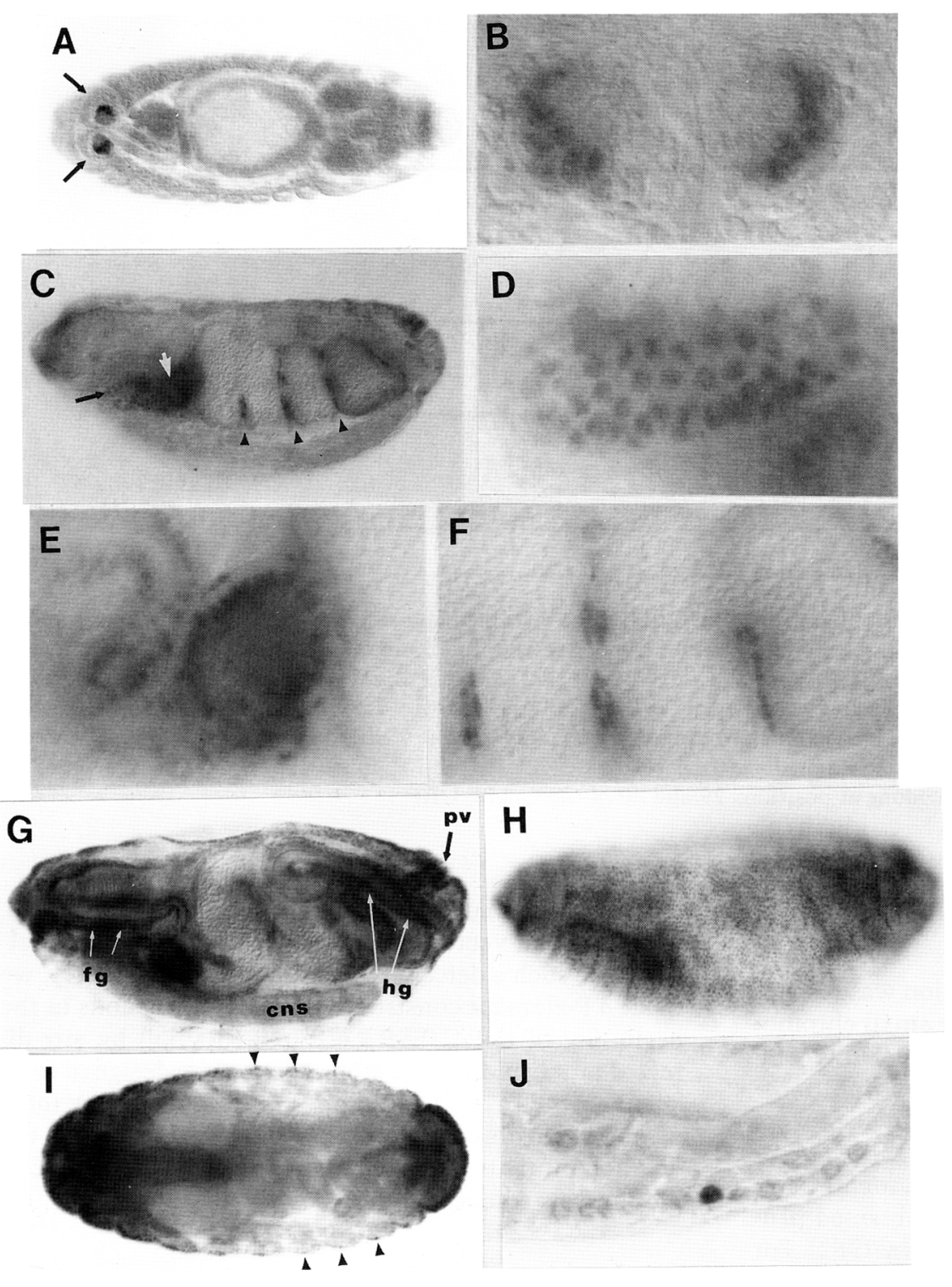

Figure 7. Localization of the C/EBP protein by the immunostaining of Drosophila embryos. The embryos were stained with a mixture of affinity-purified $\mathrm{C} 135$ $(1: 200)$ and $\mathrm{Cl} 143(1: 500)$ anti-DmC/EBP antibodies, preadsorbed to 0 - to $4-\mathrm{hr}$ embryos before use. Each antibody alone gave the same staining pattern (as did C138), but less intense. Preimmune sera gave only overall background staining (non-nuclear). The orientation of the embryos is standard-anterior to the left, posterior to the right-and for side views $(C, G, H)$, dorsal is up and ventral is down. Embryo developmental stages are given as approximate time at $25^{\circ} \mathrm{C}$. (A) A 10-hr-old embryo in dorsal view; $(B)$ a higher magnification of the staining at the posterior spiracles; (C) a 13-hr-old embryo with a black arrow pointing at the salivary gland (higher magnification in $D$ ), a white arrow pointing at the proventriculus (higher magnification in E), and arrowheads pointing at the midgut region (higher magnification in $F$ ); $\langle G, H\rangle$ two focal planes of the same 15-hrold embryo: interior $(G)$ and surface $(H)$. The posterior spiracles $(\mathrm{pv})$, foregut ( $\mathrm{fg}$, pharynx and esophagus), hindgut (hg), and central nervous system (cns) are indicated. Note the fore- and hindgut staining as well as the general epidermal staining. Panel I shows a dorsal view of a 17-hr embryo, emphasizing the pattern of late epidermal and gut staining at the ends of the embryo. Singular nuclei staining in the middle of the embryo is marked by arrowheads. I is a higher magnification one epidermal segment from the embryo in $I$. scription unit. The $\mathrm{P}$ elements define a genetic locus called slbo and cause homozygous flies to be female sterile or weakly fertile (Montell et al. 1992). Starting with two of these P-element slbo alleles (Fig. 8, slbo ${ }^{1}$ and $\left.s l b o^{r y}\right)^{\prime}$ we generated excision derivatives by exposing the P-element-bearing flies to transposase [( $\Delta 2-3 \mid 99 \mathrm{~B})]$ (Robertson et al. 1988) and established independent stocks of excision derivatives as described by Cohen et al. (1992). Several such excision derivatives $13 / 56$ for $s l b o^{1}$ and $3 / 70$ for $\left.s 1 b o^{r y}\right)$ were homozygous lethal and lethal over the deficiency $D f(2 R) P x^{2}$, which uncovers the slbo locus. They also failed to complement each other and the original, P-element-induced slbo mutation that caused female sterility. Southern blot analysis /data not shown) of these alleles showed that the excision events had deleted DNA flanking the P element, including the $\mathrm{C} / \mathrm{EBP}$ promoter region and all or part of the coding region. The genomic structures of two C/EBP deletion al- leles, $1(2) s 1 b o^{e 7 b}$ and $1(2) s 1 b o^{r y 8 e \times 22}$, are indicated in Figure 8 . These deletions are small, and the only known gene that is affected by them is C/EBP, which suggests that C/EBP is an essential gene in Drosophila.

We determined the lethal phase of homozygotes for each of the C/EBP deletion mutants as late embryonic lethal. Immunohistochemical staining confirmed that homozygous C/EBP mutant embryos did not contain the C/EBP protein, whereas their heterozygous siblings did (data not shown). The mutant embryos had a wild-type cuticle pattern, indicating no detectable alteration of epidermal patterning and differentiation by the lack of $\mathrm{C} / \mathrm{EBP}$ in the epidermis. Whole-mount mutant embryos, as well as dissected internal tissues such as the gut, were examined by light microscopy with phase-contrast and Nomarski optics but revealed no obvious morphological defects. Nevertheless, the embryos lacking C/EBP died just before or just upon hatching. 

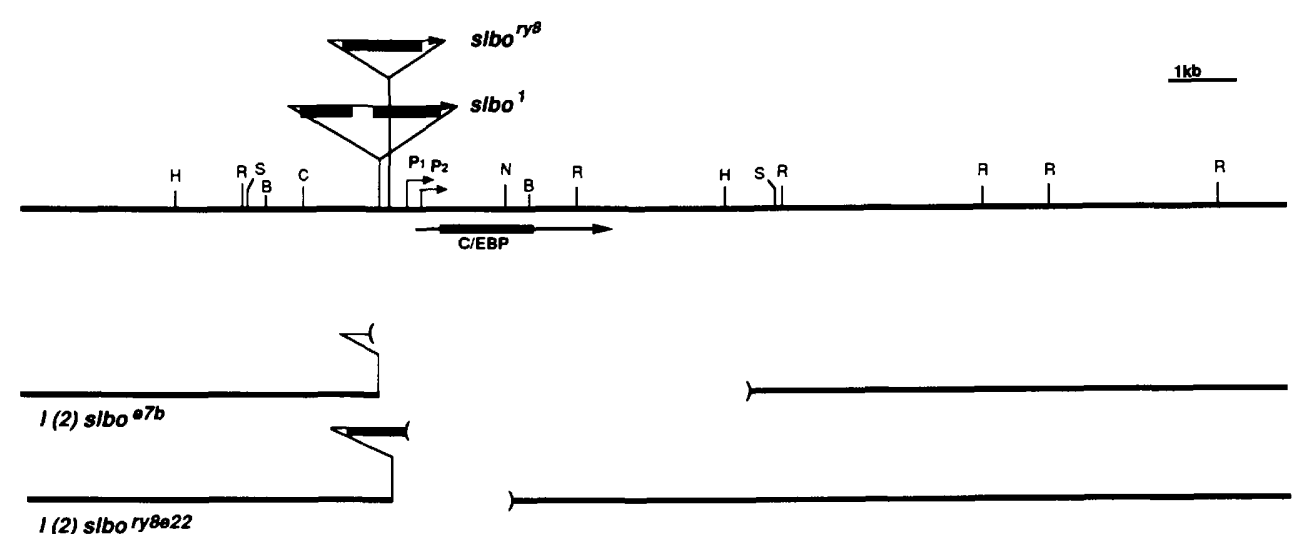

I(2) s/bory8e22

P[B-RR]
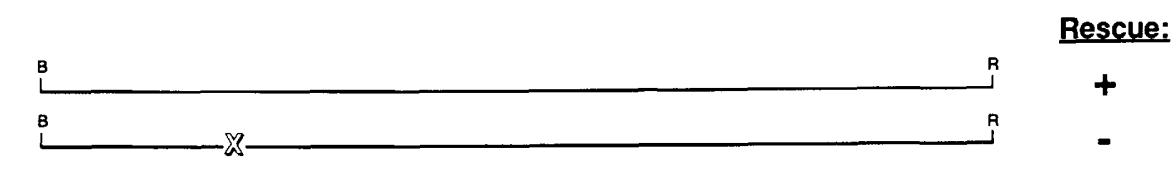

Figure 8. Map of the DmC/EBP genomic region, the slbo locus. The C/EBP gene is located at cytological position $60 \mathrm{C}$ on the second chromosome (Montell et al. 1992). The C/EBP-coding region (thick line), transcript (thin line), and promoters $\mathrm{P} 1$ and $\mathrm{P} 2$ are indicated. Restriction enzyme sites shown are HindIII (H), EcoRI (R), SalI (S), ClaI (C), NotI (N), and BglII (B). The two slbo P-element insertions are not drawn to scale. The slbo-ry $8 \mathrm{P}$ element contains the rosy gene and is $9 \mathrm{~kb}$ long; the slbo-1 P element is a $15-\mathrm{kb} \mathrm{PZ}$ enhancer trap, containing the lacZ gene and the rosy gene. The genomic structure of two C/EBP deletion alleles are shown in the middle; the $B g I I I-E c o R I$ fragment that was cloned into the pCasper transformation vector to generate $\mathrm{p}[\mathrm{B}-\mathrm{RR}]$ for rescue experiments is indicated below. The p[B-RRstop] vector contains stop codons at positions 29 and 30 of the C/EBP ORF.

Rescue of embryonic lethality by germ-line transformation with the C/EBP gene

To demonstrate that lack of C/EBP function was responsible for the lethality associated with the small chromosomal deletions, we introduced the cloned DmC/EBP gene into flies by P-element-mediated germ-line transformation. The C/EBP gene and flanking sequences were cloned into a P-element vector p[B-RR] (Fig. 8, see legend), the constructs were injected into Drosophila embryos, and germ-line transformants were obtained $(\mathrm{Ru}$ bin and Spradling 1982; Spradling and Rubin 1982). For each transformant, the $\mathrm{P}$ element carrying the C/EBP gene was mapped to a chomosome and crossed into a C/EBP deletion mutant background. In four of four independent transformants, the presence of one such ectoptic copy of the normal C/EBP gene allowed the homozygous deletion mutants described above to survive to adulthood, consistent with C/EBP being required for embryonic viability. However, only $2-60 \%$ of the expected number of rescued adults eclosed, the percentage varying with the P-element insertion site and genomic background. The incomplete rescue, coupled with the dependency on the genomic location, suggested that the rescuing $\mathrm{P}$ element lacked some regulatory sequences required for normal expression of the C/EBP gene.

The original analysis of the slbo locus (Montell et al. 1992) revealed a long open reading frame (ORF) with good Drosophila codon usage on the strand complimentary to the C/EBP-coding strand. Although we had not found any mRNA corresponding to this strand, there was still the possibility that it had escaped our detection and that deletion of this ORF was the cause of the embryonic lethality observed in the deletion mutants. In addition, the P-element vectors described above could theoretically rescue such a defect. To eliminate this possibility, we made a P-element construct with two stop codons in the beginning of the C/EBP ORF (p[B-RRstop]) by site-directed mutagenesis. The stop codons were designed to be silent in the opposite strand ORF. In four of four independent transformants, $\mathrm{p}$ [B-RRstop] failed to rescue the deletion mutants, showing that expression of the C/EBP protein was essential for Drosophila development.

\section{Discussion}

Any cell of a higher eukaryotic organism requires expression of essentially two kinds of genes: those for basic housekeeping functions that take place in most or all cells, and those that carry out the specialized functions of that particular cell. The mammalian transcription factor C/EBP $(\mathrm{C} / \mathrm{EBP}-\alpha)$ is involved in expression of the second type of genes, the differentiation-specific genes. This conclusion is based on the observations that many cells in the organism and most tissue culture cells do not contain the C/EBP protein and that C/EBP has been shown to transcriptionally activate tissue-specific genes in hepatocytes (Friedman et al. 1989) and adipocytes (Christy et al. 1989). One of the distinguishing features of C/EBP is that it is not only expressed in a single differentiating tissue, but in a particular set of tissues, and that it may regulate different target genes in each cell type. These observations raise two questions: Is C/EBP actually required in each of the tissues in which it is expressed, and what other proteins does C/EBP cooper- 
ate with in the different tissues to transcriptionally activate the proper repertoire of tissue-specific genes? To begin to address these questions we have turned to Drosophila to undertake a genetic analysis of the roles of C/EBP in vivo.

We have shown here that the product of the Drosophila C/EBP gene is similar to its mammalian counterpart, both with respect to the structural and functional properties of the protein and with respect to its apparent biological function. Two similarities between Drosophila and mammalian C/EBP were observed when comparing the overall structures of the genes: (1) The genes are intronless; and (2), the encoded protein products have the bZIP domains at their carboxyl termini. The bZIP domains of the mammalian C/EBPs are the domains responsible for DNA binding; they are also well conserved between members of the C/EBP family. Thus, conservation of this domain tentatively placed DmC/EBP within the C/EBP family; however, in the absence of any obvious sequence similarity outside of the bZIP region, the sequence alone did not classify DmC/EBP as a homolog of any individual mammalian C/EBP family member.

One of the obvious differences between Drosophila and mammalian systems was that we found only one C/EBP in Drosophila, whereas at least five to six family members have been identified in mammals. If other C/EBPs exist in Drosophila, they would have to be more divergent from DmC/EBP than DmC/EBP is from the mammalian C/EBPs in the basic region or greatly underrepresented in the genomic library screened. It would not be surprising, however, if there were only a single $\mathrm{DmC} /$ EBP, because there are many examples of families of mammalian genes corresponding to single Drosophila genes, such as each of the paralogous groups of homeotic genes (for review, see McGinnis and Krumlauf 1992).

Within the characteristic bZIP domain of DmC/EBP, both the basic region and the leucine zipper were found to be functionally equivalent to their counterparts in the mammalian proteins. The amino acid sequences of the basic regions in all mammalian C/EBPs and in DmC/EBP show a striking degree of conservation: $80-90 \%$ sequence identity. The observation that $\mathrm{DmC} / \mathrm{EBP}$ displayed sequence-specific DNA recognition indistinguishable from that of $\mathrm{C} / \mathrm{EBP}-\alpha$ was not surprising, as the basic region is thought to dictate DNA-binding specificity. Nevertheless, it is intriguing that 23 of 29 amino acids in the basic region are identical between DmC/EBP and mammalian $\mathrm{C} / \mathrm{EBP}$, when only a minority of the amino acids are predicted to contact DNA directly (Vinson et al. 1989; O'Neil et al. 1990). This part of the C/EBP protein may be responsible for interactions other than making sequence-specific DNA contacts, as has been implied for the DNA-binding basic region of myogenic helix-loop-helix proteins (Davis et al. 1990; Brennan et al. 1991) and the homeo domain of Oct-1 (Stern et al. 1989). Requirement for such interactions would provide additional selective pressure for conservation of the basic region sequence.

The leucine zipper of DmC/EBP was found to mediate dimerization despite both conservative (methionine) and nonconservative (histidine) substitutions of leucine in the heptad repeat. In addition, the dimerization specificity of the leucine zipper was maintained from C/EBP- $\alpha$ to $\mathrm{DmC} / \mathrm{EBP}$, despite only $22 \%$ amino acid identity between them. Many of the differences between C/EBP- $\alpha$ and DmC/EBP are conservative substitutions, particularly among the hydrophobic amino acids that alternate with the leucines of the heptad repeat in the coiled-coil dimerization interface and among the adjacent charged amino acids. These two groups of residues are believed to dictate dimerization specificity (O'Neil et al. 1990). But why has the dimerization specificity been maintained, if there are no additional C/EBP isoforms that can heterodimerize with Drosophila C/EBP? One possibility is that this zipper specificity is required to prevent interaction of C/EBP with other cellular bZIP proteins such as Jun and Fos, which are found in both mammals and flies (Perkins et al. 1990). Alternatively, other proteins that specifically dimerize with C/EBP, for example, the negative regulator CHOP-10 (Ron and Habener 1992), may be present in both mammals and in Drosophila.

The functional similarity between DmC/EBP and mammalian C/EBP appeared to extend beyond the level of protein structure. The expression pattern of $\mathrm{Dm}$ $\mathrm{C} / \mathrm{EBP}$ in the embryo was by several independent criteria reminiscent of the expression pattern of C/EBP- $\alpha$ in mammals, suggesting that $\mathrm{DmC/EBP}$ may serve the same functions as mammalian C/EBPs and, in particular, C/EBP- $\alpha$. As is the case for C/EBP- $\alpha$, DmC/EBP was not required for the cellular housekeeping function, as it was only expressed in a subset of cells. For example, neither C/EBP- $\alpha$ nor DmC/EBP was found in any cells early in embryogenesis. For both proteins, the first detectable expression was late in embryogenesis, when different organs and tissues had become morphologically distinct and the cells were in the late stages of differentiation (this study; Birkenmeier et al.1989; Kuo et al. 1990; Z. Cao, P. Rфrth, and S. McKnight, unpubl.). In Drosophila as in mammals, C/EBP expression was not confined to one single tissue but to a specific set of epithelial tissues. Two examples of parallel expression of DmC/EBP and C/EBP- $\alpha$ are the cells lining the gut and in the epidermis of the Drosophila embryo, and the corresponding intestinal lining and skin in mammals. We emphasize the similarity between the types of tissues and cells that express C/EBP, although there are obviously great differences between, for example, epidermal cells of Drosophila and those of mammals.

It has been noted that C/EBP- $\alpha$ is restricted to the postmitotic, terminally differentiating cells of the tissues in which it is expressed (with the exception of myelomonocytic cells (Scott et al. 1992). Similarly, we have found expression of DmC/EBP only in postmitotic, differentiating cells. The observation that expression of C/EBP in differentiating tissues is maintained throughout life in mammals, but is transient in Drosophila embryos, may reflect the differences in cell growth and differentiation in these organisms. In mammals there is a continuing proliferation and differentiation process in most somatic tissues throughout life; in Drosophila 
most somatic tissues are not continuously replenished, so the differentiation process itself may be transient.

The similarities in expression patterns of DmC/EBP and $C / E B P-\alpha$ discussed above raise the possibility that the two C/EBPs regulate some common target genes in the respective organisms. One putative target gene for $\mathrm{C} / \mathrm{EBP}$ regulation in both systems is the alcohol dehydrogenase $(A d h)$ gene, which is expressed in the mammalian liver and in the Drosophila fat body. C/EBP- $\alpha$ transcriptionally activates the human $A d h-2$ gene in cultured hepatoma cells through C/EBP-binding sites in the promoter region (Stewart et al. 1990). Interestingly, one of the C/EBP-binding sites critical for activation of Adh-2 is located between the TATA box and the transcription initiation site, reminiscent of the C/EBP site that we have identified in the promoter of the DmC/EBP gene. More recent evidence suggests that differential effects of several C/EBP family members are critical for determining the temporal expression pattern and expression level of all three human class I $A d h$ genes (van Ooij et al. 1992). In Drosophila, Falb and Maniatis (1992) identified a cis-acting regulatory unit in the adult fat body enhancer for $A d h$, which is of similar structure to a corresponding unit in the promoter of human $A d h$. Mammalian C/EBP is capable of activating transcription by this $A d h$ regulatory unit in transfection experiments. Because of the embryonic lethality associated with null mutations in C/EBP, we have not determined whether $\mathrm{DmC}$ /EBP described in this study regulates $A d h$ expression in the adult fat body; but if that is the case, it would strengthen the parallels between gene regulation by $\mathrm{C} / \mathrm{EBP}$ in mammals and flies.

We have determined that $\mathrm{C} / \mathrm{EBP}$ is essential during late Drosophila embryogenesis, presumably because $\mathrm{C} / \mathrm{EBP}$ normally regulates other genes required for development. Analyses of mammalian C/EBP have suggested that different genes respond to C/EBP in each of the C/EBP-expressing tissues, and this may also be the case in Drosophila. Although the tissues that express $\mathrm{C} / \mathrm{EBP}$ in the embryo play rather dissimilar physiological roles, one function common to most of these tissues is the secretion of cuticle that initiates coincident with $\mathrm{C} / \mathrm{EBP}$ expression. We have not found any defects in the cuticle of C/EBP mutant embryos thus far, and further studies will be required to determine the defects in the mutants and to elucidate which genes are actually the critical target genes for C/EBP in the developing Drosophila embryo.

We found a high affinity binding site for C/EBP in the promoter region of the $\mathrm{DmC} / \mathrm{EBP}$ gene, which raises the possibility that $\mathrm{DmC} / \mathrm{EBP}$ regulates its own transcription. Mammalian C/EBP- $\alpha$ can also bind its own promoter, but the biological relevance of this is unknown (Christy et al. 1991). Stimulatory autoregulation resulting in stable maintenance of gene expression has been indicated for several Drosophila transcription factors, for example, Deformed (Kuziora and McGinnis 1988). Autoregulation by eve (Harding et al. 1989), fushi tarazu ( $f \mathrm{tz}$; Pick et al. 1990), and engrailed (Heemskerk et al. 1991) results in temporary enhancement of gene expres- sion. A similar transient enhancement of gene expression could account for the boost of C/EBP expression observed at 12-14 hr of embryonic development. Alternatively, C/EBP bound to a site between the TATA box and the transcription initiation site may serve as a repressor, negatively autoregulating to turn off the expression of its own gene. It should be possible to test the function of the C/EBP-binding site in the promoter of the DmC/EBP gene by mutating the site and assessing the effect of the mutation on the ability of the cloned gene to rescue the C/EBP mutants.

In conclusion, we found that DmC/EBP displayed both structural and functional resemblance to mammalian C/EBPs. The observation that the expression pattern and, possibly, the functions of C/EBP are similar in such divergent organisms as humans and flies raises some interesting possibilities. Perhaps genes that C/EBP regulates, proteins that $\mathrm{C} / \mathrm{EBP}$ cooperates with in transcriptional regulation, as well as factors that determine C/EBPs own expression pattern will turn out to be similar in the two systems. If that is the case, tissues expressing C/EBP in Drosophila and the mammalian systems, such as the embryonic epidermis and the skin, may share patterns of transcriptional control and thus be more similar than is immediately apparent. In any case, the study of the evolutionarily well-conserved C/EBP in Drosophila is likely to bring results that are also relevant for mammalian C/EBPs. In vitro mutagenesis of the C/EBP gene coupled with Drosophila germ-line transformation should permit analysis of C/EBP structure and function in the context of the development of a complex multicellular organism.

\section{Materials and methods}

\section{Overexpression and purification of the C/EBP protein}

The complete C/EBP-coding region was cloned into bluescript $(\mathrm{SK}+)$ and into the E. coli expression vector pT5 (Studier and Moffatt 1986) by polymerase chain reaction (PCR)-mediated addition of a BamHI site onto the $5^{\prime}$ end and a HindIII site onto the $3^{\prime}$ end (after the C/EBP stop codon) of the ORF using oligonucleotides 5'-AGAGGATCCAACATGGAGTCGCCG-3' and 5'-GGAAGCTTCGGCTACAGCGAGTG-3', respectively. Cloned genomic DNA was used as template, as C/EBP has no introns. Similarly a BamHI site was placed $5^{\prime}$ to codon 354 , using oligonucleotide 5'-AGAGGATCCGTGGACAAGGGCACG-3' to produce the BRLZ protein. This resulted in an inframe fusion, adding only Met-Gly-Ser from the vector onto the C/EBP protein. To delete the polyglutamine stretch lopa repeat), codons 45-67 were looped out and replaced in-frame with an EcoRI site (Asn-Ser) by oligo-directed mutagenesis. The expression vectors were transformed into BL21 cells, and C/EBP overexpression was induced by IPTG. Inclusion bodies were purified by standard procedures (Harlow and Lane 1988), solubilized by $5 \mathrm{M}$ guanidinium- $\mathrm{HCl}$, and dialyzed into $100 \mathrm{mM} \mathrm{KCl}$ $10 \mathrm{~mm}$ Tris $\{\mathrm{pH} 7.5\}, 1 \mathrm{~mm}$ DTT, $1 \mathrm{~mm}$ EDTA, $1 \mathrm{~mm}$ benzamidine, and 0.5 mM PMSF. After removing insoluble material, the proteins were loaded onto an FPLC S-Sepharose column (Pharmacia) and eluted with increasing $\mathrm{KCl}$ concentration. Fractions were analyzed on SDS-polyacrylamide gels, and those containing essentially pure C/EBP protein were dialyzed back to 100 $\mathrm{mM} \mathrm{KCl}$ buffer and used for DNA-binding experiments. For the 
comparative analysis, $\mathrm{C} / \mathrm{EBP}-\alpha$ proteins, as well as $\mathrm{GlCl}$, were expressed and purified in essentially the same manner. The protein referred to as full-length $\mathrm{C} / \mathrm{EBP}-\alpha$ was the C/EBP $\alpha \Delta \mathrm{I}-2$ derivative (Friedman and McKnight 1990), which was overexpressed in $E$. coli using the pT5 expression vector described above.

\section{Preparation of C/EBP antisera and affinity purification}

Rabbits were injected and bled at Spring Valley Laboratories (Woodbine, MD). Purified recombinant C/EBP proteins prepared as described above and shown schematically in Figure 1B (o7 for C143 antiserum and BRLZ for C135 antiserum), or carboxy-terminal amino acid peptide (CRSFLNTNEHSL, for C138 antiserum) coupled to keyhole limpet hemacyanin (KLH, from Sigma), were used as antigens and mixed with Freund's adjuvant before injection. These antisera recognized the native $\mathrm{DmC} /$ EBP protein /recombinant DmC/EBP from $E$. coli, as well as endogenous DmC/EBP from Drosophila embryo nuclear extracts) in EMSA and denatured E. coli-expressed DmC/EBP in Western blot analysis.

For affinity purification, the antibodies were first passed over a protein A-Sepharose column (Pharmacia) and IgGs were eluted with glycine ( $\mathrm{pH} 3.0)$. The IgGs were then passed over a column with C/EBP (07) protein immobilized on Affi-gel 10 beads (Bio-Rad), or BSA-coupled peptide on Affi-gel 15 beads for C138, followed by extensive washing $(10 \mathrm{~mm}$ Tris at $\mathrm{pH} 7.4$, $0.1 \%$ Triton $\mathrm{X}-100$ and $10 \mathrm{~mm}$ Tris at $\mathrm{pH} 7.4,0.1 \%$ Triton $\mathrm{X}-100,0.5 \mathrm{M} \mathrm{NaCl})$. Specific antibodies were eluted with glycine $(\mathrm{pH} 2.5)$, and $0.1 \%$ Triton $\mathrm{X}-100$, neutralized by Tris buffer $(\mathrm{pH}$ 8.0 ), stabilized with $5 \%$ normal goat serum (Sigma), and dialyzed. The presence of specific antibodies in the fractions was detected by EMSA.

For Western analysis, embryos were collected from a population cage containing $\mathrm{P} 2$ flies, and after appropriate aging at $25^{\circ} \mathrm{C}$, rinsed, dechorionated, and weighed. Total protein was extracted in SDS-sample buffer with a B-pestle Dounce, samples were boiled for 2-3 $\mathrm{min}$, and insoluble material was removed before loading onto SDS-polyacrylamide gels for Western blotting. For detection, nonaffinity-purified antibody was used at $1: 200 \mathrm{di}$ lution. Whole-mount immunostaining was performed essentially as described in Patel et al. (1989). The secondary antibody was horseradish peroxidase (HRP)-coupled anti-rabbit antibody (Jackson Immunoresearch Labs), visualized by diaminobenzidine tetrahydrochloride (DAB, Sigma) $+\mathrm{NiCl}$ staining. Embryos were viewed and photographed on an Axiophot microscope (Zeiss). To identify mutant embryos in crosses, the parent flies harbored a C/EBP deletion chromosome over a CyO balancer containing a $\mathrm{ftz}-\mathrm{lacZ}$ fusion construct. Presence or absence of the balancer in embryos was scored by anti- $\beta$-galactosidase staining.

\section{Northern analysis and mRNA 5' end mapping}

RNA was isolated from embryos by guanidinium solubilization and centrifugation through a $5.7 \mathrm{M} \mathrm{CsCl}$ cushion. Poly $(\mathrm{A})^{+}$ RNA was selected by binding to oligo(dT) beads. The RNA was electrophoresed through a formaldehyde gel and blotted onto GeneScreen membranes, all by standard methods (Sambrook et al. 1989|. The filters were probed with random primer-labeled DNA probe in $50 \%$ formamide, $6 \times \mathrm{SSC}, 0.1 \% \mathrm{BSA}, 0.1 \%$ Ficoll, $0.1 \%$ polyvinylpyrolidone, and $100 \mathrm{mg} / \mathrm{ml}$ of denatured salmon sperm DNA at $42^{\circ} \mathrm{C}$ and washed in $0.1 \% \mathrm{SSC}, 0.1 \% \mathrm{SDS}$, at $65^{\circ} \mathrm{C}$ (stringent wash).

Primer extension and Sl protection analyses were carried out by standard methods (Sambrook et al. 1989). Hybridization was in $250 \mathrm{mM} \mathrm{KCl}, 20 \mathrm{~mm}$ Tris (pH 8.0), and $1 \mathrm{~mm}$ EDTA at $90^{\circ} \mathrm{C}$ for $2 \mathrm{~min}$, and at $68^{\circ} \mathrm{C}$ for $2 \mathrm{hr}$, followed by slow cooling to $40^{\circ} \mathrm{C}$ and addition of buffer and enzyme for primer extension or for $\mathrm{S} 1$ digestion. The three synthetic oligonucleotides used for primer extension 5'-CTGCCGTTGGCTAGTACTCTCGT-3', 5'-CAGTTTGTTACTTTGTTAACTCGACACTGCAC-3' and 5'CGGCGTACATCTGCGGCGACTCCATGTTAAGC-3', hybridize between residues +168 to $+146,+278$ to +247 , and +578 to +547 , respectively. The primers were labeled at the $5^{\prime}$ end with polynucleotide kinase and $\left[\gamma^{-32} \mathrm{P}\right] \mathrm{gATP}$, hybridized to poly $(\mathrm{A})^{+}$or total embryo RNA, and extended by reverse transcriptase. For $\mathrm{Sl}$ analysis of the upstream cap site, a $5^{\prime}$-endlabeled, twice gel-purified oligonucleotide corresponding to residues +27 to -13 (5'-CGCCGACGAGTGGTAAATTGTAACTGTGACAAAACGCGAA-3') was hybridized to embryo RNA and then subjected to digestion by $\mathrm{S} 1$ nuclease. The protected fragments were analyzed on urea-polyacrylamide gels alongside negative controls (yeast RNA and mammalian embryonic stem cell RNA) and a control and size marker, in which the oligonucleotide was protected from residue +27 to residue -4 .

\section{EMSA and DNase I footprinting}

The probe for EMSA was a 5'-TGCAGATTGCGCAATCTGCA-3' oligonucleotide, labeled at the 5' end with $\left[\gamma^{-32} \mathrm{P}\right] \mathrm{ATP}$. Proteins were preincubated at room temperature for $10 \mathrm{~min}$ in $50 \mathrm{~mm} \mathrm{KCl}, 10 \mathrm{~mm}$ Tris $(\mathrm{pH} 8.0\}, 1 \mathrm{~mm}$ EDTA, $1 \mathrm{~mm}$ DTT, 1 $\mathrm{mg} / \mathrm{ml}$ of BSA (Sigma), $10 \%$ glycerol, and $0.5 \mu \mathrm{g}$ of poly[d(I-C)] in $20 \mu \mathrm{l}$. Approximately 20 fmoles of labeled probe, mixed with unlabeled competitor oligonucleotide, as indicated, was added, and the incubation continued for $20 \mathrm{~min}$ before loading onto a $6 \%$ nondenaturing polyacrylamide gel ( $1 / 2 \times \mathrm{TBE}, 5 \%$ glycerol) and electrophoresing at $300 \mathrm{~V}$ for $2-3 \mathrm{hr}$ at $4^{\circ} \mathrm{C}$.

For DNase I footprinting, the DNA fragments were digested with restriction endonuclease (MluI for +233 , NotI of the Bluescript linker adjacent to +55 , an $M s c I$ site), phosphatase treated, $5^{\prime}$-end labeled with $\left[\gamma^{-32} \mathrm{P}\right] \mathrm{ATP}$ and digested with a second enzyme to release the fragment. Purified labeled DNA fragment and protein were incubated at room temperature in $20 \mu \mathrm{l}$ of 25 mM HEPES (pH 7.9), $75 \mathrm{~mm} \mathrm{KCl,} 2 \mathrm{~mm} \mathrm{MgCl}, 0.1 \mathrm{~mm}$ EDTA, $0.2 \mathrm{~mm}$ DTT, $0.2 \mathrm{mM}$ PMSF, $12 \%$ glycerol, and $1 \mu \mathrm{g}$ of poly[d(IC)] for 15-20 min. After an additional $2 \mathrm{~min}$ of incubation in the presence of $2.5 \mathrm{mM} \mathrm{CaCl}_{2}$ and $0.1 \mathrm{ng}$ of DNase I/Worthington Diagnostics), the incubation was stopped by adding EGTA to 10 $\mathrm{mM}$ and SDS to $0.1 \%$, followed by phenol-chloroform extraction and ethanol precipitation. The products were separated on denaturing polyacrylamide gels alongside a Maxam-Gilbert $G+A$ sequencing lane of the same labeled fragment.

\section{Acknowledgments}

We thank Dr. Nipam Patel for help with whole-mount immunostaining, Dr. Jon Shuman for providing the C/EBP- $\alpha$ and GCN4 BRLZ proteins, Dr. Peter Johnson for providing the G1C1 plasmid, and Wen-Cheng Ziong for staged RNAs used in Figure 5. We also acknowledge Drs. Allan Spradling and Steven McKnight for many interesting discussions and inspiring suggestions. P.R. particularly thanks Steven McKnight for the support and encouragement she has received working in his laboratory. This work was supported in part by Howard Hughes Medical Institute funds to Steven McKnight, the Carnegie Institution of Washington, and a fellowship from the Danish Medical Research Council to P.R. D.J.M. is a Lucille P. Markey scholar, and this work was supported in part by funds from the Lucille P. Markey Charitable Trust and National Institutes of Health grant R29GM46425.

The publication costs of this article were defrayed in part by payment of page charges. This article must therefore be hereby 
marked "advertisement" in accordance with 18 USC section 1734 solely to indicate this fact.

\section{References}

Agre, P., P.F. Johnson, and S.L. McKnight. 1989. Cognate DNA binding specificity retained after leucine zipper exchange between GCN4 and C/EBP. Science 246: 922-926.

Akira, S., H. Isshiki, T. Sugita, O. Tanabe, S. Kinoshita, Y. Nishio, T. Nakajima, T. Hirano, and T. Kishimoto. 1990. A nuclear factor for IL-6 expression (NF-IL6) is a member of a C/EBP family. EMBO J. 9: 1897-1906.

Birkenmeier, E.H., B. Gwynn, S. Howard, J. Jerry, J.I. Gordon, W.H. Landschulz, and S.L. McKnight. 1989. Tissue-specific expression, developmental regulation, and genetic mapping of the gene encoding CCAAT/enhancer binding protein. Genes \& Dev. 3: 1146-1156.

Bohmann, D., T.J. Bos, A. Admon, T. Nishimura, P.K. Vogt, and R. Tjian. 1987. Human proto-oncogene c-jun encodes a DNA binding protein with structural and functional properties of transcription factor AP-1. Science 238: 1386-1392.

Brennan, T.J., T. Chakraborty, and E.N. Olson. 1991. Mutagenesis of the myogenin basic region identifies an ancient protein motif critical for activation of myogenesis. Proc. Natl. Acad. Sci. 88: 5675-5679.

Cao, Z., R.M. Umek, and S.L. McKnight. 1991. Regulated expression of three C/EBP isoforms during adipose conversion of 3T3-Ll cells. Genes \& Dev. 5: 1538-1552.

Christy, R.J., V.W. Yang, J.M. Ntambi, D.E. Geiman, W.H. Landschulz, A.D. Friedman, Y. Nakabeppu, T.J. Kelly, and M.D. Lane. 1989. Differentiation-induced gene expression in 3T3-Ll preadipocytes: CCAAT/enhancer binding protein interacts with and activates the promoters of two adipocyte specific genes. Genes \& Dev. 3: 1323-1335

Christy, R.J., K.H. Kaestner, D.E. Geiman, and M.D. Lane. 1991. CCAAT/enhancer binding protein gene promoter: Binding of nuclear factors during differentiation of 3T3-L1 preadipocytes. Proc. Natl. Acad. Sci. 88: 2593-2597.

Cohen, B., M.E. McGuffin, C. Pfeifle, D. Segal, and S.M. Cohen. 1992. apterous, a gene required for imaginal disc development in Drosophila encodes a member of the LIM family of developmental regulatory proteins. Genes \& Dev. 6: 715729.

Davis, R.L., P.-F. Cheng, A.B. Lassar, and H. Weintraub. 1990. The MyoD DNA binding domain contains a recognition code for muscle-specific gene activation. Cell 60: 733-746.

Descombes, P., M. Chojkier, S. Lichtsteiner, E. Falvey, and U. Schibler. 1990. LAP, a novel member of the C/EBP gene family, encodes a liver-enriched transcriptional activator protein. Genes \& Dev. 4: 1541-1551.

Falb, D. and T. Maniatis. 1992. A conserved regulatory unit implicated in tissue-specific gene expression in Drosophila and man. Genes \& Dev. 6: 454-465.

Freytag, S.O. and T.J. Geddes. 1992. Reciprocal regulation of adipogenesis by Myc and C/EBP. Science 256: 379-382.

Friedman, A.D. and S.L. McKnight. 1990. Identification of two polypeptide segments of CCAAT/enhancer-binding protein required for transcriptional activation of the serum albumin gene. Genes \& Dev. 4: 1416-1426.

Friedman, A.D., W.H. Landschulz, and S.L. McKnight. 1989. CCAAT/enhancer binding protein activates the promoter of the serum albumin gene in cultured hepatoma cells. Genes \& Dev. 3: 1314-1322.

Graves, B.J., P.F. Johnson, and S.L. McKnight. 1986. Homologous recognition of a promoter domain common to the MSV
LTR and the HSV tk gene. Cell 44: 565-576.

Harding, K., T. Hoey, R. Warrior, and M. Levine. 1989. Autoregulatory and gap response elements of the even-skipped promoter of Drosophila. EMBO I. 8: 1205-1212.

Harlow, E. and D. Lane. 1988. Antibodies: A laboratory manual. Cold Spring Harbor Laboratory, Cold Spring Harbor, New York.

Harrison, S.C. 1991. A structural taxonomy of DNA-binding domains. Nature 353: 715-719.

Heemskerk, J., S. DiNardo, R. Kostriken, and P. O'Farrell. 1991. Multiple modes of engrailed regulation in the progression towards cell fate determination. Nature 352: 404-410.

Hinnebusch, A.G. 1984. Evidence for translational regulation of the activator of general amino acid control in yeast. Proc. Natl. Acad. Sci. 81: 6442-6446.

Hope, I.A. and K. Struhl. 1987. GCN4, a eukaryotic transcriptional activator protein, binds as a dimer to target DNA. EMBO I. 6: 2781-2784.

Johnson, P.F., W.H. Landschulz, B.J. Graves, and S.L. McKnight. 1987. Identification of a rat liver nuclear protein that binds to the enhancer core element of three animal viruses. Genes \& Dev. 1: 133-146.

Kouzarides, T. and E. Ziff. 1988. Leucine zippers of fos, jun and GCN4 dictate dimerization specificity and thereby control DNA binding. Nature 340: 568-571.

Kuo, C.F., K.G. Xanthopoulos, and J.E. Darnell Jr. 1990. Fetal and adult localization of C/EBP: Evidence for combinatorial action of transcription factors in cell-specific gene expression. Development 109: 473-481.

Kuziora, M. and W. McGinnis. 1988. Autoregulation of a Drosophila homeotic selector gene. Cell 55: 477-485.

Landschulz, W.H., P.F. Johnson, E.Y. Adashi, B.J. Graves, and S.L. Mcknight. 1988. Isolation of a recombinant copy of the gene encoding C/EBP. Genes \& Dev. 2: 786-800.

Landschulz, W.H., P.F. Johnson, and S.L. Mcknight. 1989. The DNA binding domain of the rat liver nuclear protein C/EBP is bipartite. Science 243: 1681-1688.

Lin, F.-T. and M.D. Lane. 1992. Antisense CCAAT/enhancerbinding protein RNA suppresses coordinate gene expression and triglyceride accumulation during differentiation of 3T3L1 preadipocytes. Genes \& Dev. 6: $533-544$.

McGinnis, W. and R. Krumlauf, 1992. Homeobox genes and axial patterning. Cell 68: 283-302.

Montell, D.J., P. Rørth, and A.C. Spradling, 1992. slow border cells, a locus required for a developmentally regulated cell migration during oogenesis, encodes Drosophila C/EBP. Cell 71: $51-62$.

O'Neil, K.T., R.H. Hoess, and W.F. DeGrado. 1990. Design of DNA-binding peptides based on the leucine zipper motif. Science 249: 774-778.

Patel, N.H., E. Martin-Blanco, K.G. Coleman S.J. Poole, M.C. Ellis, T.B. Kornberg, and C.S. Goodman. 1989. Expression of engrailed proteins in arthropods, annelids, and chordates. Cell 58: 955-968.

Perkins, K.K., A. Admon, N. Patel, and R. Tjian. 1990. The Drosophila Fos-related AP-1 protein is a developmentally regulated transcription factor, Genes \& Dev. 4: 822-834.

Pick, L., A. Schier, M. Affolter, T. Schmidt-Glenewinkel, and W.J. Gehring. 1990. Analysis of the $f t z$ upstream element: Germ layer-specific enhancers are independently autoregulated. Genes \& Dev. 4: 1224-1239.

Poli, V., F.P. Mancini, and R. Cortese. 1990. IL-6DBP, a nuclear protein involved in interleukin- 6 signal transduction, defines a new family of leucine zipper proteins related to C/EBP. Cell 63: 643-653.

Robertson, H.M., C.R. Preston, R.W. Phillis, D.M. Johnson- 
Schlitz, W.K. Benz, and W.R. Engels. 1988. A stable genomic source of $\mathrm{P}$ element transposase in Drosophila melanogaster. Genetics 118: 461-470.

Roman, C., J.S. Platero, J. Shuman, and K. Calame. 1990. Ig/ EBP-1: A ubiquitously expressed immunoglobulin enhancer binding protein that is similar to and heterodimerizes with C/EBP. Genes \& Dev. 4: 1404-1415.

Ron, D. and J.F. Habener. 1992. CHOP, a novel developmentally regulated nuclear protein that dimerizes with transcription factors C/EBP and LAP and functions as a dominant-negative inhibitor of gene transcription. Genes \& Dev. 6: 439453.

Rubin, G.M. and A.C. Spradling. 1982. Genetic transformation of Drosophila with transposable element vectors. Science 218: 348-353.

Sambrook, J., E.F. Fritsch, and T. Maniatis. 1989. Molecular cloning: A laboratory manual. Cold Spring Harbor Laboratory Press, Cold Spring Harbor, New York.

Samuelsson; L., K. Stromberg, K. Vikman, G. Bjursell, and S. Enerback. 1991. The CCAAT/enhancer binding protein and its role in adipocyte differentiation: evidence for direct involvement in terminal adipocyte development, $E M B O \mathrm{~J}$. 11: 3787-3793.

Scott, L.M., C.I. Civin, P. Rørth, and A.D. Friedman. 1992. A novel temporal expression pattern of three C/EBP family members in differentiating myelomonocytic cells. Blood 80: 1725-1735.

Shuman, J., C.R. Vinson, and S.L. McKnight. 1990. Evidence of changes in protease sensitivity and subunit exchange rate on DNA binding by C/EBP. Science 249: 771-774.

Spradling, A.C. and G.M. Rubin. 1982. Transposition of cloned P elements into Drosophila germ line chromosomes. Science 218: 341-347.

Stern, S., M. Tanaka, and W. Herr. 1989. The Oct-1 homoeodomain directs formation of a multiprotein-DNA complex with the HSV transactivator VP16. Nature 341: 624-630.

Stewart, M.J., M.L. Shean, and G. Duester. 1990. Trans activation of human alcohol dehydrogenase gene expression by C/EBP molecules bound in a novel arrangement just $5^{\prime}$ and $3^{\prime}$ to the TATA box. Mol. Cell. Biol. 10: 5007-5010.

Studier, F.W. and B.A. Moffatt. 1986. Use of a bacteriophage T7 RNA polymerase to direct selective high-level expression of cloned genes. I. Mol. Biol. 189: 113-130.

Umek, R.M., A.D. Friedman, and S.L. McKnight. 1991. CCAAT-enhancer binding protein: A component of a differentiation switch. Science 251: 288-292.

van Ooij, R.C. Snyder, B.W. Paeper, and G. Duester. 1992. Temporal expression of the human alcohol dehydrogenase gene family during liver development correlates with differential promoter activation by hepatocyte nuclear factor 1 , CCAAT/enhancer binding protein a, liver activator protein and D-element-binding-protein. Mol. Cell. Biol. 12: 30233031 .

van Straaten, F., R. Müller, T. Curran, C. van Beveren, and I.M. Verma. 1983. Complete nucleotide sequence of a human c-onc gene: Deduced amino acid sequence of the human c-fos protein. Proc. Natl. Acad. Sci. 80: 3183-3187.

Vinson, C.R., P.B. Sigler, and S.L. McKnight. 1989. Scissors-grip model for DNA recognition by a family of leucine zipper proteins. Science 246: $911-916$.

Williams, S.C., C.A. Cantwell, and P.F. Johnson. 1991. A family of C/EBP-related proteins capable of forming covalently linked leucine zipper dimers in vitro. Genes \& Dev. 5: 15531567. 


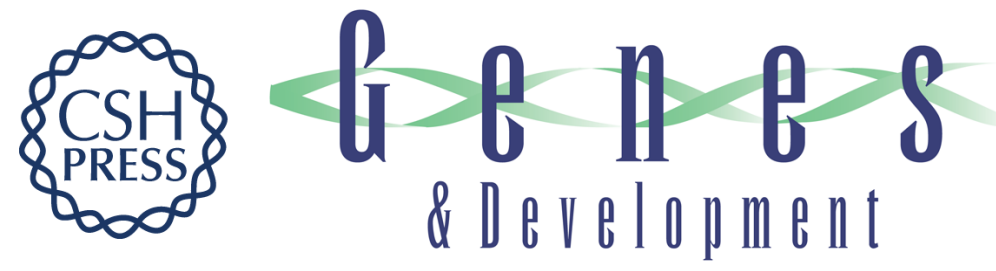

\section{Drosophila C/EBP: a tissue-specific DNA-binding protein required for embryonic development.}

P Rørth and D J Montell

\section{Genes Dev. 1992, 6:}

Access the most recent version at doi:10.1101/gad.6.12a.2299

References This article cites 51 articles, 35 of which can be accessed free at:

http://genesdev.cshlp.org/content/6/12a/2299.full.html\#ref-list-1

License

Email Alerting

Service

Receive free email alerts when new articles cite this article - sign up in the box at the top right corner of the article or click here.

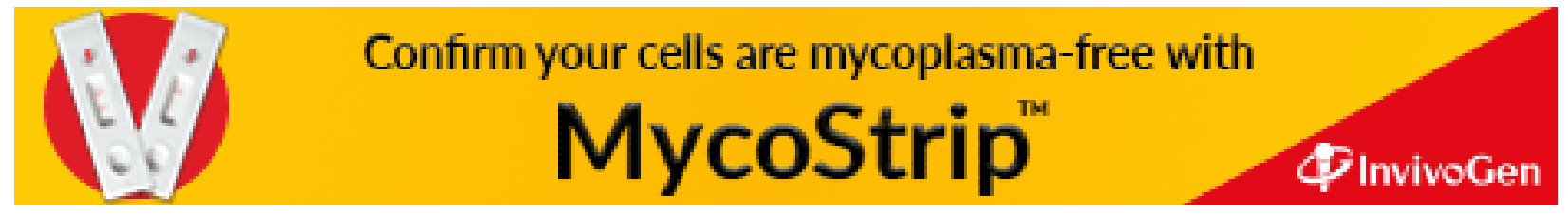

